\title{
PENDIDIKAN INFORMAL SIKAP TOLERANSI ANAK (EKSTERNALISASI SIKAP TOLERANSI ANAK DALAM KELUARGA MULTIAGAMA DI DESA 'PANCASILA' TURI LAMONGAN JAWA TIMUR
}

\author{
Dr. Nasruddin, S.Pd, M.A \\ Dosen UIN Sunan Ampel Surabaya \\ nasruddin@uinsby.ac.id
}

\begin{abstract}
Abstrak
Balun dikenal dengan sebutan desa Pancasila. Ada 3 agama hidup dan berkembang di Balun. Pemeluk ketiga agama tersebut hidup secara rukun, harmoni dan bertoleransi. Kehidupan ini tidak bisa dilepaskan dari peran lembaga-lembaga pendidikan yang ada di Balun. Namun, lembaga pendidikan yang memiliki peran sangat penting dalam membentuk sikap toleransi pada anak adalah lembaga pendidikan informal. Dalam menamamkan sikap toleransi pada anak, keluarga multiagama melakukan proses eksternalisasi sikap toleransi melalui pendidikan informal, sehingga tulisan ini memfokuskan kajiannya pada 'eksternalisasi sikap toleransi anak melalui pendidikan informal dalam keluarga multiagama di Balun Turi Lamongan. Tujuan ini adalah menguraikan proses eskternalisasi sikap toleransi anak melalui pendidikan informal dalam keluarga multiagama di Balun Turi Lamongan.

Penelitian ini menggunakan metode penelitian kualitatif, dan peneliti sebagai kunci utama. Untuk mendapatkan data, tulisan menggunakan observasi partisipasi, wawancara mendalam, dan studi dokumentasi. Untuk menganalisis data, peneliti menggunakan model Spreadly.

Penelitian ini menemukan proses eksternalisasi sikap toleransi anak melalui pendidikan informal dalam keluarga multiagama di Balun Turi Lamongan dalam bentuk (i) pengucapan 'selamat hari raya', (ii) menerima perbedaan dan saling menghormati, dan (iii) tidak mendeskritkan ibadah umat lain. Proses eskternalisasi dalam ketiga bentuk tersebut adalah (a) menyesuaikan diri dengan masyarakat terkait sikap toleransi yang ada, (b) menggunakan pesan singkat (WA, SMS, atau lainnya) sebagai media penyesuaian diri atas sikap toleransi di masyarakat, (b) mengajak anak-anak langsung bertamu dan ketemu dengan orang-orang berbeda agama satu persatu atau dari rumah ke rumah sebagai identifikasi diri, (d) mencontohkan anakanak bersikap toleransi di masyarakat berdasarkan pengetahuan sebelumnya, dan (e) menemukan pijakan atau sandaran dalam membentuk sikap toleransi anak.
\end{abstract}

\section{Pendahuluan}

Dalam konteks relasi antar agama, tidak ada desa yang paling terkenal di wilayah kabupaten Lamongan, kecuali desa Balun. Desa ini tidak hanya dihuni oleh umat Islam saja, melainkan juga oleh umat-umat agama lain seperti Kristen dan Hindu. Keberadaan agama Kristen dan Hindu tidak hanya diakui oleh pemerintahan 
desa Balun, tetapi juga diayomi keberadaan mereka. Begitu juga, setiap aktivitas keagamaan kedua agama ini (Kristen dan Hindu) juga dilindungi. Pengakuan, pengayoman dan perlindungan oleh pemerintahan desa Balun terhadap agama lain (Kristen dan Hindu) ini menjadikan desa Balun terasa sangat istimewa dan langka ${ }^{1}$ jika dibandingkan dengan desa-desa yang ada di wilayah Lamongan lainnya. Sehingga, tidak mengherankan jika desa Balun menjadi sangat terkenal, dan dijadikan sebagai desa percontohan atau 'desa model' bagi kerukunan antar umat beragama, baik di tingkatan lokal (kabupaten), regional (propinsi) maupun nasional.

Pengakuan, pengayoman dan perlindungan pemerintahan desa Balun terhadap ketiga agama (Islam, Kristen dan Hindu) ini menjadikan desa Balun dikenal sebagai desa Pancasila. Sebagai desa Pancasila, desa Balun tidak hanya mengakui keanekaragaman agama, pengayoman dan perlindungan terhadap umat beragama dan rumah-rumah ibadah, melainkan juga memperlakukan secara adil dan bijak atas segala kegiatan dan aktivitas keagamaan bagi masing-masing agama. Artinya, setiap pemeluk di desa Balun berhak dan bebas untuk menjalankan aktivitas atau ritual keagamaan mereka tanpa ada halangan, larangan, intimidasi, kekerasan dan sejenis dari siapapun maupun dari manapun, termasuk dari pemerintahan desa Balun. Sehingga, tidak salah jika desa Balun disebut sebagai desa Pancasila.

Keterkenalan desa Balun sebagai desa Pancasila ternyata tidak hanya pada level antar kabupaten atau kota di Jawa Timur, ${ }^{2}$ melainkan juga pada level antar propinsi. Beberapa orang dari luar Jawa Timur pernah mengunjungi desa Balun. Informan $\mathrm{R}^{3}$ dan $\mathrm{M}^{4}$ menuturkan bahwa orang-orang dari luar Jawa Timur yang datang ke desa Balun berasal dari Semarang, Yogyakarta, DKI Jakarta, dan bahkan

\footnotetext{
${ }^{1}$ Dikatakan langka karena tidak ada desa lain di daerah Lamongan yang memiliki agama lebih dari dua (baca: Islam dan Kristen), kecuali desa Balun.

${ }^{2}$ Kabupaten Lamongan berbatasan dengan beberapa kabupaten yang lain. Di sebelah barat, kabupaten Lamongan berbatasan dengan kabupaten Bojonegoro dan Tuban. Di sebelah selatan, kabupaten Lamongan berbatasan dengan kabupaten Jombang dan kota atau kabupaten Mojokerto. Sedangkan, di sebelah timur kabupaten Lamongan berbatasan dengan kabupaten Gresik.

${ }^{3} \mathrm{R}$ merupakan Kaur Keuangan desa Balun sekarang.

${ }^{4} \mathrm{M}$ merupakan anggota Bappeda Lamongan.
} 
ada yang berasal dari Jayapura Papua. ${ }^{5}$ Lebih lanjut, R dan M menyatakan bahwa orang yang datang dari Papua tidak hanya terdiri dari satu atau dua orang, melainkan rombongan. Kedatangan rombongan Jayapura ke desa Balun ingin mengetahui keadaan kehidupan keberagamaan, dan ingin menyaksikan langsung pola keberagamaan keseharian masyarakat desa Balun, tanpa ada rekayasa atau manipulasi di dalamnya. Hasil kunjungan rombongan Jayapura ke desa Balun ini digunakan sebagai bahan acuan atau masukan kepada pemerintah setempat (baca: kabupaten Jayapura) tentang bagaimana mengelola keragaman etnis, budaya, bahasa, agama, dan bagaimana memperlakukan umat beragama di Jayapura secara adil, sehingga menjadi kekuatan bersama. ${ }^{6}$ Oleh karena itu, kemasyhuran desa Balun ini tidak hanya menarik perhatian banyak orang dari Jawa Timur saja, melainkan juga dari luar Jawa Timur.

Desa Balun, sebagai desa Pancasila, juga tidak hanya menarik perhatian nasional saja, tetapi juga perhatian dunia. Beberapa warga manca negara pernah tercatat mengunjungi desa antar iman ini. Warga negara asing tersebut berasal dari Malaysia, ${ }^{7}$ Belgia dan Korea. ${ }^{8}$ Mereka tidak hanya ingin mengunjungi dan melihat keadaan desa Balun semata, tetapi mereka ingin menyaksikan kehidupan keberagamaan dan interaksi antar umat beragama secara langsung. ${ }^{9}$ Sayangnya, kedatangan warga negara asing ini (Belgia dan Korea) dalam waktu yang sangat

\footnotetext{
${ }^{5}$ Pernyataan ini disampaikan Rudi di ruangan kerja sekdes dan di hadapan aparat desa lainnya pada tanggal 11 November 2016.

${ }^{6}$ Wawancara dengan M di balai desa Balun, 18 November 2016. Terkait dengan kunjungan rombongan Papua, informan $\mathrm{R}$ maupun $\mathrm{M}$ menyatakan bahwa mereka (orang-orang Jayapura) kembali lagi setelah 1 bulan berlalu. Mereka meminta cap stempel desa Balun sebagai tanda atau bukti bahwa mereka telah melakukan tugas mereka.

${ }^{7}$ Menurut mantan Kaur Kesra, R, dan anggota Bappeda Lamongan, M bahwa dua tahun lalu ada 2 warga Johor Malaysia yang mengunjungi dan melakukan penelitian di desa Balun selama kurang 1 Bulan, dan mereka tidak pernah lagi kembali ke desa Balun setelah penelitian mereka selesai. Namun sayangnya, ketika peneliti bertanya tentang 'siapa nama dan apa posisinya?, aparat desa yang tinggal dekat dengan Pondok Pesantren Jamhar ini tidak menjawab. Ia mengatakan bahwa ia 'lupa nama mereka' (wawancara di balai desa Balun, 11 November 2016).'

${ }^{8}$ Peristiwa terjadi pada bulan November 2016.

${ }^{9}$ Peneliti mendapatkan informasi ini ketika penelitia makan jajanan atau snack di warung Sri dekat masjid Miftahul Huda dan Pura Sweta Maha Suci (tanggal 15 November 2016). Peneliti juga mengkonfirmasi info tersebut kepada mantan Dekan FKIP UNISLA, CYS karena adiknya, yang studi S2 di Belgia, yang mengantar kedua warga asing tersebut ke desa Balun.
} 
pendek. Di samping itu, kedua warga negara Belgia dan Korea ini menginap dan menetap di kota Lamongan daripada di desa Balun. Dengan demikian, tidak salah jika desa Balun diklaim sebagai desa rujukan bagi hubungan antar umar agama karena desa ini berhasil dalam mengelola keragaman agama dan kebhinnekaan umat, sehingga menarik mata dunia untuk datang dan menstudinya.

Sikap toleransi yang terjadi selama ini di desa Balun tidak bisa dilepaskan dari lembaga-lembaga pendidikan yang ada di dalamnya. Lembaga-lembaga pendidikan yang ada di desa Balun bukan hanya lembaga pendidikan yang bersifat formal saja, melainkan juga ada lembaga pendidikan bersifat non formal dan informal. Sehingga, lembaga-lembaga pendidikan yang ada di desa Balun memiliki peranan yang sangat signifikan untuk penciptaan sikap toleransi antar umat beragama.

Berdasarkan hasil observasi atau survey, peneliti mencatat bahwa desa Balun pernah memiliki lembaga pendidikan formal, yaitu: TK Pembangunan, TKM Jamhar, SDN I Balun, SDN II Balun, SDN III Balun dan MI Tarbiyatus Sibyan. Jika dilihat dari latar belakang agama keluarga, para peserta didik (para siswa) baik di tingkatan PG/TK maupun SD/MI berasal dari berbagai agama. Artinya, para siswa yang sekarang sedang bersekolah di TK al-Jamhar dan MI Tarbiyatus Sibyan sangat mungkin berasal dari keluarga multi agama. Meskipun, kita tidak bisa memungkiri bahwa semua siswa yang bersekolah di PG/TK al-Jamhar dan MI Tarbiyatus Sibyan beragama Islam. Dengan kata lain, para siswa yang bersekolah di MI Tarbiyatus Sibyan $100 \%$ beragama Islam. Meskipun begitu, hal ini tidak berarti bahwa seluruh anggota keluarga atau orang yang tinggal bersama anak-anak yang bersekolah di MI Tarbiyatus Sibyan ini beragama Islam semua. Sebaliknya, beberapa siswa MI Tarbiyatus Sibyan ini hidup dan tinggal bersama anggota keluarga mereka yang masih beragama non Islam (Kristen dan Hindu).

Berbeda dengan para siswa yang bersekolah di TK al-Jamhar dan MI Tarbiyatus Sibyan, para siswa yang bersekolah di SDN I Balun dan SDN II Balun tidak hanya berasal dari keluarga multiagama saja, melainkan mereka juga memeluk agama yang berbeda-beda. Ada siswa yang beragama Islam yang bersekolah di kedua SDN ini hidup dan tinggal satu rumah dengan anggota keluarga mereka yang berbeda 
agama. Artinya, anggota keluarga sebagian siswa ini memiliki agama yang berbedabeda. Ada anggota keluarga siswa yang beragama Kristen, dan juga ada anggota keluarga siswa yang beragama Hindu ${ }^{10}$

Begitu juga, anak-anak yang bersekolah di TK Pembangunan merupakan para siswa yang berasal dari keluarga multiagama. Sekolah tingkat anak usia dini ini sangat terbuka, dan menerima pendaftaran siswa dari seluruh agama yang ada di desa Balun, yaitu: Islam, Kristen atau Hindu. Artinya, TK Pembangunan tidak membeda-bedakan siswa atau anak didik berdasarkan latar belakang agama mereka. Semua anak desa Balun bisa bersekolah di TK Pembangunan.

Hal tersebut sedikit berbeda dengan anak-anak yang belajar di TKM alJamhar. Seluruh anak yang belajar di TKM Jamhar beragam Islam, meskipun mereka berasal dari keluarga multi agama. Dengan kata lain, ada di antara siswa TK ini yang masih hidup dan tinggal dengan anggota keluarga yang beragama selain Islam (Kristen dan Hindu).

Dengan demikian, para siswa yang sekarang bersekolah baik di TKM alJamhar, TK Pembangunan, SDN I Balun, SDN II Balun, maupun MI Tarbiyatus Sibyan merupakan siswa-siswi yang berasal dari keluarga multi agama, atau setidaknya ada anggota keluarganya yang berbeda agama.

Lembaga-lembaga pendidikan non formal di desa Balun juga memberikan sumbangsih dan peran nyata bagi pemeliharaan dan pengembangan sikap toleransi pada diri anak. Berdasarkan pengamatan peneliti, keberadaan Pondok Pesantren (ponpes) Jamhar memberikan kontribusi bagi pemeliharaan sikap toleransi pada diri anak Islam. Ponpes Jamhar bukan ponpes yang mengajarkan nilai-nilai kekerasan, kekakuan, dan keekslusifan pada diri anak. Di samping itu, ponpes ini juga tidak menanamkan sikap benci dan agitatif pada diri anak, sehingga mereka akan selalu membenci agama lain atau penganut agama selain Islam. Sebaliknya, ponpes ini berpartisipasi dalam menebarkan dan melestarikan nilai-nilai Islam yang ramah, yaitu menumbuhkan sikap toleransi, sikap moderat, dan sikap seimbang pada diri anak dengan berbasiskan pada ciri ke-Indonesia-an.

\footnotetext{
${ }^{10}$ Wawancara dengan NY, tanggal 5 dan 18 Desember 2016, dan M, tanggal 5 Desember 2016.
} 
Proses pendidikan di Balun tidak hanya berlangsung di sekolah, madrasah, pondok pesantren, melainkan juga berlangsung di dalam rumah tangga atau keluarga. Keluarga sebagai lembaga pendidikan informal memainkan peranan yang sangat penting dan signifikan dalam melahirkan generasi-generasi Balun yang toleran. Sebelum belajar di lembaga-lembaga pendidikan formal maupun non formal, anakanak telah belajar terlebih dahulu pada keluarga mereka. Di dalam keluarga, anakanak belajar dan mempelajari sesuatu dengan menggunakan telinga mereka untuk mendengar, memahami dan menirukan apa yang orang tua atau keluarga katakan, bicarakan, perbincangkan, diskusikan dan seterusnya. Begitu juga, anak-anak menggunakan mata mereka untuk melihat apa yang ada dan terjadi di dalam keluarga mereka.

Keluarga di desa Balun - berdasarkan hasil wawancara dan pengamatan peneliti - memegang peran yang sangat signifikan dan menentukan dalam pembentukan sikap toleransi pada diri anak; apakah itu anak yang masih duduk di bangku play group maupun di sekolah dasar. ${ }^{11}$ Mengapa demikian? karena keluarga memiliki waktu yang sangat banyak untuk bersama anak-anak di rumah dibandingkan dengan para guru atau pengkursus di sekolah maupun kursus (les) dan pondok pesantren.

Anak-anak di sekolah hanya menghabiskan waktu antara 2,5 sampai 5 jam sehari, selebihnya mereka menghabiskan waktu bersama keluarga di rumah. Anakanak yang berusia play group dan bersekolah di kelompok bermain atau TK misalnya, mereka hanya menghabiskan waktu paling lama 2,5 jam di sekolah. Mereka selanjutnya akan menghabiskan waktu 21,5 jam bersama keluarga mereka di rumah. Begitu juga, anak-anak yang bersekolah di sekolah dasar hanya menghabiskan waktu belajar mereka di sekolah sekitar 5 jam. Selebihnya, mereka akan menghabiskan waktu mereka di rumah dengan keluarga.

Hal demikian di atas terjadi karena praktek pendidikan dan proses pembelajaran yang ada di PG/TK dan SDN/MI di Balun hanya berjalan mulai dari jam 7 dan berakhir jam 12 siang. Bahkan, peneliti mencatat anak-anak sudah pulang 
lebih dahulu sebelum jam menunjukkan pukul 12 siang. Sehingga, anak-anak hanya menghabiskan waktu mereka di sekolah tidak lebih dari 5 jam perhari, selebihnya mereka menghabiskan waktu 19 jam atau lebih bersama keluarga mereka di rumah. Oleh karena itu, keluarga memiliki kesempatan yang luas dan leluasa dalam membentuk karaktek dan sikap toleransi pada diri anak.

Peran sentral dan menentukan keluarga dalam pembentukan sikap toleransi pada diri anak, terutama anak yang berusia dini dan sekolah dasar, diakui oleh para guru, baik di lembaga pendidikan formal maupun non formal yang ada di Balun. Dalam mengkonstruksi sikap toleransi pada diri anak-anak, orang tua di Balun tidak hanya mengajak anak-anak mereka menghadiri acara-acara selamatan, kenduri dan sejenisnya, melainkan orang tua juga membiarkan anak-anak mereka belajar dan bermain bersama di dalam atau di luar rumah. Bahkan, keluarga terkadang merelakan anak-anak mereka bermain bersama keluar desa Balun dengan menaiki sepeda onthel atau sepeda angin. Pembiaran anak untuk bermain dengan temannya yang berbeda agama ini memberikan kesempatan yang luar biasa bagi anak-anak untuk menambah keakraban, saling memahami, saling mengerti di antara mereka, dan sebagai ajang untuk mengeksplorasi kemampuan social di antara mereka. ${ }^{12}$

Tidak hanya itu, anak-anak keluarga multi agama juga terbiasa berkunjung ke rumah teman-teman dan guru-guru mereka yang berbeda agama. Apa yang dilakukan oleh anak-anak keluarga antar agama ini belum bisa, jika tidak dikatakan tidak bisa, dilakukan oleh anak-anak yang yang berasal dari keluarga seagama atau seiman. Sehingga, tidah mengherankan jika anak-anak keluarga multi agama memiliki sikap toleransi yang lebih tinggi atau aktif daripada anak-anak keluarga seiman atau segama dalam merespon atau menghadapi perbedaan yang ada di desa Balun.

\footnotetext{
${ }^{12}$ Peneliti mengamati keluarga Ibu Guru A merupakan salah satu keluarga yang membiarkan anaknya untuk bermain dan bergaul dengan siapa saja, tanpa melihat latar belakang agama teman-teman anaknya. Keluarga ibu guru, lulusan SMAN 3 Lamongan 7 tahun lalu, ini membiarkan anaknya bermain kelereng di depan rumah tetangga atau lainnya, bermain layang-layang di jalanan desa, atau bermain sepak bola bersama dengan teman-temannya di lapangan sepak bola setelah mereka selesai mengaji Qira'ati di pesantren al-Jamhar
} 
Karakter baik dan atau sikap toleransi yang ada pada keluarga multiagama di atas setidaknya bisa dibaca pada kehidupan keluarga EL, keluarga Rik dan keluarga Pur. Ketiga keluarga beda agama ini tampak hidup dalam bingkai kedamaian, keharmonisan, kerukunan, ketentraman, kenyamanan, saling mendukung dan menolong di antara sesama anggota keluarga. ${ }^{13}$ Meskipun pada ketiga keluarga ini ada anggota yang berbeda keyakinan atau agama, namun perlakukan diskriminatif atau tidak adil tidak pernah terjadi pada tiga keluarga ini.

Sikap toleransi dalam keluarga tiga multiagama di atas bukanlah sikap yang lahir secara spontanitas, melainkan melalui proses pendidikan yang lama dan terjadi di dalam lingkungan keluarga multiagama mereka. Oleh karena itu, pendidikan dalam keluarga multi agama memegang peranan yang sangat penting dan siginifikan sekali dalam membentuk sikap toleransi pada diri anak di Balun. Sehingga, kajian yang meneliti pendidikan informal dengan cara eksternalisasi sikap toleransi anak dalam keluarga multiagama di desa 'Pancasila' Balun Turi Lamongan menjadi sangat menarik dan penting untuk dilakukan.

Dengan merujuk pada paparan konteks di atas, fokus utama kajian ini adalah 'Bagaimana pendidikan informal dalam keluarga multiagama mengeskternalisasi sikap toleransi pada anak di desa 'Pancasila' Balun Turi Lamongan?' Sehingga, tujuan kajian ini adalah menguraikan proses eksternalisasi sikap toleransi anak melalui pendidikan informal dalam keluarga multiagama di Desa 'Pancasila' Balun Turi Lamongan.

\section{Metode Penelitian}

\footnotetext{
${ }^{13}$ Peneliti melihat sendiri LS duduk-duduk santai bersama di rumah. Mereka tampak tenang dengan menikmati tontonan TV secara bersama. Begitu juga dengan keluarga Rik dan keluarga Pur. Mereka berdua tanpa ada beban sosial dalam hidupnya meskipun ada anggota keluraga yang tidak seagama dengan mereka.
} 
Metode penelitian yang dipakai dalam penelitian ini adalah pendekatan kualitatif ${ }^{14}$ karena (i) mempertanyakan 'apa dan bagaimana,' ${ }^{15}$ (ii) topik yang diteliti dalam penelitian ini memerlukan eksplorasi lebih dalam lagi, (iii) menyajikan dan menyuguhkan sikap toleransi sebagai realitas sosial atau fakta kehidupan masyarakat Balun secara lebih gamblang dan jelas sehingga enak dicerna, dibaca dan dinikmati, (iv) berusaha mempelajari dan mengkaji subjek penelitian dengan latar penelitian yang alamiah, apa adanya, tanpa ada rekayasa dari peneliti; (v) peneliti memiliki waktu yang cukup untuk mencari subyek penelitian yang unik dan bisa dijadikan informan selama penelitian berlangsung, (vi) peneliti bisa menceritakan realitas sosial obyektif maupun subyektif yang dialami sendiri oleh peneliti melalui partisipan observasi tanpa mengaku sebagai seorang yang ahli atau pakar. ${ }^{16}$ Paradigma yang

${ }^{14}$ Mackey, Alison. Second Language Research: Methodology and Design. New Jersey: Lawrence Erlbaum Associates, Inc. 2005, 162-7, lihat juga Nagy, Sharlene and Hesse-Biber. Mixed Methods Research: Merging Theory with Practice. New York: The Guilford Press, 2010, 67-72; Imron Arifin. Penelitian Kualitatif dalam Ilmu-ilmu Sosial dan Keagamaan. Malang: Kalimasahada Press, 1994, 10-12, 16-21; Mudrajat Kuncoro. Metode Riset. Jakarta: Erlangga. 2003, 2-3; Robert Bogdan \& Steven J. Taylor. Dasar-dasar Penelitian Kualitatif. Terj. A. Khozin Afandi. Surabaya: Usaha Nasional, 1975, 26-30, 36-37; Bruce L Berg. Qualitative Research Methods for the Social Science. USA: Allyn dan Bacon, 1989, 1-7; Thomas R. Lindlof. Qualitative Communication Research Methods. USA: SAGE Publications, Inc. 1995, 18-22, 56-58; David Silvermen. Interpreting Qualitative Data: Methods for Analyzing Talk, Text, and Interaction. Great Britain: the Crowell Press, ltd, 1995, 20-29.

${ }^{15}$ Thomas R. Lindlof. Qualitative Communication Research Methods. USA: SAGE Publications, Inc. 1995, 69-80, 82, 88, 90 dan 94; Mudrajat Kuncoro. Metode Riset. Jakarta: Erlangga. 2003, 23-26, 33-35; Bruce L Berg. Qualitative Research Methods for the Social Science. USA: Allyn dan Bacon, 1989, 2-8; Matthew Miles B \& A. Michael Huberman. Analisis Data Kualitatif. Terj. Tjejep Rohendi. Jakarta: UI, tt, 38-45; Donald Ary et.all. Introduction to Research in Education. USA: Holt Rinehart and Winston, tt, 41-55; James Dean Brown. Understanding Research in Second Language Learning. NY: Cambridge Univ. Press, tt, 211-220.

${ }^{16}$ M. Djunaidi Ghony dan Fauzan Almanshur. Metodologi Penelitian Kualitatif. Yogyakarta: ar-Ruz Media. 2012, 91-93. Sebagai bandingan, lihat J. W. Creswell. Qualitative Inquiry and Research Design Choosing Among Five Traditions, Thousand Oaks: Sage, 1998, dan Mixed Method Research: Introduction and Application, dalam G. J. Cizek, Ed. Handbook of Educational Policy. San Diego: Academic Press, 1998. Lihat juga, Sanapiah Faisal. Format-format Penelitian Sosial: Dasar -dasar dan Aplikasi. Jakarta: Raja Grafindo Persada, 1995, 20; Nana Syaodih Sukmadinata. Metode Penelitian Pendidikan. Bandung: Remaja Rosdakarya, 2006, 18, 60-66, 72; James A. Black dan Dean J. Champion. Metode dan Masalah Penelitian Sosial. Bandung: Refika Aditama, 2001, 69-70; Masykuri Bakri, Dkk. Metode Penelitian Kualitatif: Tinjauan Teoritis dan Praktis. Malang: LP UNISMA 
dipakai dalam penelitian ini adalah paradigma post-positivistik ${ }^{17}$ dengan jenis fenomenologi, ${ }^{18}$ karena peneliti ingin mencari atau menemukan makna di balik realitas sosial dan atau fakta yang ada ${ }^{19}$ di desa Balun, dan bagaimana subyek penelitian (keluarga multi agama) mengalami realitas sosial atau fakta kehidupan tersebut.

Model penelitian kualitatif yang dipakai dalam penelitian ini adalah studi kasus, ${ }^{20}$ karena (i) penelitian ini meneliti tentang suatu 'kesatuan sistem' yang berupa peristiwa, kejadian, atau lainnya yang dialami oleh subyek penelitian baik secara individu maupun kelompok yang terikat waktu dan tempat (desa Balun), (ii) peneliti hanya akan menjadikan warga desa Balun terutama keluarga multi agama yang menetap di Balun saja sebagai subyek penelitian, (iii) peneliti menyuguhkan realitas sosial dan atau fakta kehidupan yang ada hanya di desa Balun, bukan di tempat lainnya, (iv) peneliti mengumpulkan informasi-informasi yang bisa digunakan sebagai alat atau media untuk membantu memecahkan persoalan yang dihadapi subyek penelitian, (v) peneliti bisa menarik kesimpulan atau hasil temuan penelitian secara cermat, dan (vi) kesimpulan hasil penelitian ini bersifat kasuistik. Artinya,

Malang, 2013, 52; Punaji Setyosari. Metode Penelitian Pendidikan dan Pengembangan. Jakarta: Prenadamedia Group, 2015, 58-9.

${ }^{17}$ Jan Jocker dan Bartjan Pennink. The Essence of Research Methodology: A Concise Guide for Master and PhD Students in Management Science. Berlin: Springer, 2010, 80-81.

${ }^{18}$ Untuk memahami lebih jelas dan detail tentang fenomenologi, lihat Imron Arifin. Op.cit, 1994, 45-62; Mudrajat Kuncoro. Op.cit. 2003, 23-26, 8-9; Bruce L Berg. Op.cit. 1989, 5178; Donald Ary et.all. Op.cit. tt, 295-324; Robert Bogdan \& S Knopp Biklen. Op.cit. 1990, 37-47, 254-294; James Spreadly. Participant Observation. USA: Holt Rinehart and Winston, 1980, 175-179. Imron Arifin. Op.cit. 1994, 45-56 (Orientasi Teoritik Pendekatan dan Metode); Robert Bogdan \& Steven J. Taylor. Dasar-dasar Penelitian Kualitatif. Terj. A. Khozin Afandi. Surabaya: Usaha Nasional, 1975, 44-50; Bruce L Berg. Qualitative Research Methods for the Social Science. USA: Allyn dan Bacon, 1989, 6-7; Thomas R. Lindlof. Qualitative Communication Research Methods. USA: SAGE Publications, Inc. 1995, 27-33, 40-44, 46-48, 94; David Silvermen. Interpreting Qualitative Data: Methods for Analyzing Talk, Text, and Interaction. Great Britain: the Crowell Press, ltd, 1995, 8-19.

${ }^{19}$ John W. Creswell. Penelitian Kualitatif \& Desain Riset. Yogyakarta: Pustaka Pelajar, 2014. 105-281.

${ }^{20}$ Mackey, Alison. Second Language Research: Methodology and Design. New Jersey: Lawrence Erlbaum Associates, Inc. 2005, 171-3, lihat juga Joanna Swann and John Pratt. Educational Research in Practice: Making Sense of Methodology. London: Continuum, 2003, 111-125. 
kesimpulan hasil penelitian ini nantinya tidak bisa diberlakukan pada semua keluarga multi agama yang ada di tempat lain secara over generalization. ${ }^{21}$

Instrumen dalam penelitian ini adalah peneliti sendiri. Karena peneliti bisa (1) bereaksi terhadap segala stimulus dari lokasi penelitian yang harus diperkirakan memiliki makna atau tidak bagi penelitian; (2) berinteraksi dengan situasi dan keadaan yang senantiasa berubah pada lokasi penelitian; (3) menyesuaikan diri dengan segala keadaan yang ada pada lokasi penelitian dan mampu mengumpulkan beragam data sekaligus; (4) menangkap situasi yang ada dan terjadi di lokasi penelitian secara keseluruhan; (5) memahami dan meyelami interaksi yang terjadi antar manusia pada lokasi penelitian; (6) segera menganalisis data yang diperoleh dari lokasi penelitian; dan (7) mengambil kesimpulan berdasarkan data yang diperoleh di lokasi penelitian dengan segera. ${ }^{22}$

Sumber data dalam penelitian ini dibedakan menjadi tiga, yaitu: (1) sumber data primer, (2) sumber data sekunder, dan (3) sumber data pelengkap. Sumber data primer penelitian ini adalah orang tua dan anggota keluarga multi agama. Sumber data sekunder dalam penelitian ini adalah anggota keluarga multi agama yang beragama non Islam. Sedangkan, sumber data pelengkap dalam penelitian ini adalah masyarakat Balun dan dokumen-dokumen tentang pembentukan sikap toleransi anak pada masyarakat Balun, terutama pada keluarga multiagama.

Untuk memperoleh data dalam penelitian ini, peneliti menggunakan teknik pengumpulan data yang meliputi: observasi partisipatif, wawancara mendalam, dan

\footnotetext{
${ }^{21}$ M. Djunaidi Ghony dan Fauzan Almanshur. Op.cit, 2012, 62-65. Lihat juga, Sulistyo Basuki, Metode Penelitian. Jakarta: Wedatama Widya Sastra dan Fakultas Ilmu Pengetahuan Sosial UI, 2006, 113-114, Andi Prastowo. Metode Penelitian Kualitatif dalam Perspektif Rancangan Penelitian. Yogyakarta: ar-Ruz Media. 2012, 187-188, Pradip Kumar Sahu. Research Methodology: A Guide for Researchers in Agricultural Science, Social Science and Other Related Fields. India: Springer, 2013, 72-75, Yogesh Kumar Singh. Fundamental of Research Methodology and Statistic. Delhi: New Age International, 2006, 147-161. Hal ini berbeda dengan Joanna Swann and John Pratt. Educational Research in Practice: Making Sense of Methodology. London: Continuum, 2003, 164-173.

${ }^{22}$ M. Djunaidi Ghony dan Fauzan Almanshur. Op.cit, 2012, 96-97.
} 
studi dokumentasi secara menyeluruh. ${ }^{23}$ sedangkan, untuk menguji keabsahan data, saya sebagai peneliti lebih menggunakan uji kredibilitas data (validitas internal) daripada menggunakan uji dependabilitas (reliabilitas) data, uji transferbilitas (validitas eksternal/generalisasi), dan uji konfirmabilitas (obyektivitas). ${ }^{24}$ Alasan penggunaan uji kredibilitas data (validitas internal) karena uji keabsahan data ini dianggap lebih pas dan cocok dalam konteks penelitian kualitatif dan dibenarkan secara akademik karena dilakukan melalui 7 teknik, yaitu: perpanjangan pengamatan, peningkatan ketekunan, tringulasi, ${ }^{25}$ focused group discussion (FGD), member check, ${ }^{26}$

${ }^{23}$ Yogesh Kumar Singh. Fundamental of Research Methodology and Statistic. Delhi: New Age International, 2006, 212-222, lihat juga Geoffrey Marczyk, David DeMatteo, and David Festinger. Essentials of Behavioral Science Series. New Jersey: John Wiley \& Sons, Inc, 2005, 95-123, Cavallo, Roger E. The Role of Systems Methodology in Social Sciences Research. Boston: Martinus Nijhoff Publishing, 1979, 139-143, Mackey, Alison. Second Language Research: Methodology and Design. New Jersey: Lawrence Erlbaum Associates, Inc. 2005, 173-8; Imron Arifin. Op.cit. 1994, 45-56; Robert Bogdan \& Steven J. Taylor. Op.cit 1975, 31-33, 59-77, 81-125, 157-190; Bruce L Berg. Op.cit. 1989, 13-22, 26-40, 4-5; Thomas R. Lindlof. Op.cit. 1995, 124-130, 132, 135-139, 153-160, 163-194, Matthew Miles B \& A. Michael Huberman. Analisis Data Kualitatif. Terj. Tjejep Rohendi. Jakarta: UI, tt, 58-72; Donald Ary et.all. Op.cit. tt, 129-136, 173-194.

${ }^{24}$ Ibrahim Bafadal dan Masykuri Bakri. Metode Penelitian Kualitatif: Tinjauan Teoritis dan Praktis. Malang: LP UNISMA dan Visipress Media, 2013, 185-187.

${ }^{25}$ Tringulasi merupakan proses pengecekan data sehingga dikatakan valid. Tringulasi sendiri dibagi menjadi tiga, yaitu: (1) trangulasi teori, (2) trangulasi sumber data, dan (3) trangulasi metode. Trangulasi teori data merupakan proses pengecek kevalidan data dengan menggunakan dua teori atau lebih. Trangulasi sumber adalah proses pengecekan kevalidan data dengan menanyakan satu informan dalam waktu yang berlainan, atau bertanya kepada dua informan atau lebih. Trangulasi metode adalah proses pengecekan data dengan membandingkan metode pengumpulan data. Untuk keterangan lebih detail, lihat $\mathrm{M}$. Djunaidi Ghony dan Fauzan Almanshur. Op.cit, 2012, 218-220, 322-324. Lihat juga Sugiyono. Metode Penelitian Kuantitatif, Kualitatif dan R \& D. Bandung: Alfabeta, 2014, 267-278.

${ }^{26}$ Member Check merupakan upaya pengecekan kevalidan data dengan memberikan informan untuk berkomentar, mereaksi dan lainnya terhadap data yang telah terkumpul. Untuk lebih detail, lihat M. Djunaidi Ghony dan Fauzan Almanshur. Op.cit, 2012, 328-329. 
analisis kasus negatif ${ }^{27}$ dan penggunaan referensial. ${ }^{28}$

Adapun teknik analisis data yang dipakai dalam penelitian ini adalah model Spreadly yang meliputi: (i) analisis domain, (ii) analisis taksonomi, (iii) analisis komponen, dan (iv) analisis tema (budaya). ${ }^{29}$ Berikut merupakan analisis data model Spreadly.

\section{Analisis Domain: ${ }^{30}$}

- Strict inclusion

- Kyai

- Pendeta

- Pandita

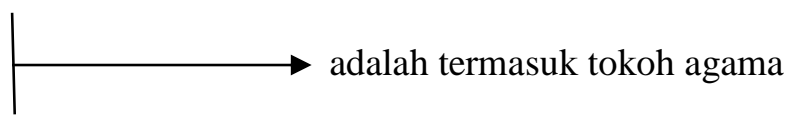

- $\quad$ Ruang/tempat (space)

- Halaman rumah

- Ruang tamu

- Kamar tidur

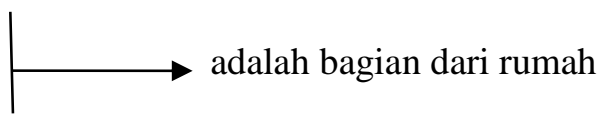

- Cause-effect

- Tidak memaksakan agama pada orang lain

- Menghormati ritual keagamaan orang lain

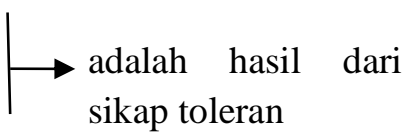

- Mengakui perbedaan budaya dan agama

- Rational

- Bersikap toleran

- Tidak memaksakan kehendak

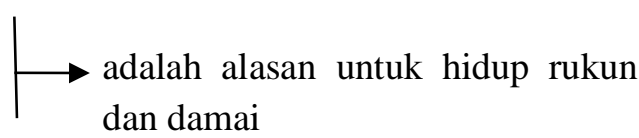

- Tidak berkonflik

${ }^{27}$ Analisis Kasus Negatif merupakan upaya pengecekan kevalidan data dengan membandingkan data yang tidak diinginkan atau tidak sesuai dengan yang diharapkan. Misalnya, semua anak keluarga multi agama diharapkan memiliki sikap toleransi yang lebih tinggi daripada anak yang berasal dari keluarga yang sama agama, namun fakta tidak demikian. Fakta sebaliknya ini yang dijadikan data pembanding. Untuk memahami lebih jelas dan detail tentang analisis kasus negative, lihat M. Djunaidi Ghony dan Fauzan Almanshur. Op.cit, 2012, 324-326.

${ }^{28}$ Untuk keterangan lebih lanjut dan detail, lihat Sugiyono. Metode Penelitian Kuantitatif, Kualitatif dan R \& D. Bandung: Alfabeta, 2014, 267-278. Lihat juga Andi Prastowo. Metode Penelitian Kualitatif dalam Perspektif Rancangan Penelitian. Yogyakarta: 2012, 265-277.

${ }^{29}$ M. Djunaidi Ghony dan Fauzan Almanshur. Op.cit, 2012, 304-307; lihat juga Sugiyono. Op.cit. 2014, 253-67.

${ }^{30}$ M. Djunaidi Ghony dan Fauzan Almanshur. Op.cit, 2012, 258-263. 
- Location for action

- Masjid

- Gereja

- Pura adalah tempat untuk menyembah Tuhan

- Function

- TK

- SD

- Ponpes

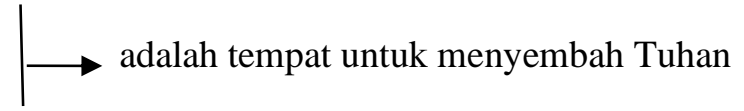

Means-end

- Menjaga gereja

- Merayakan ogoh-ogoh bersama

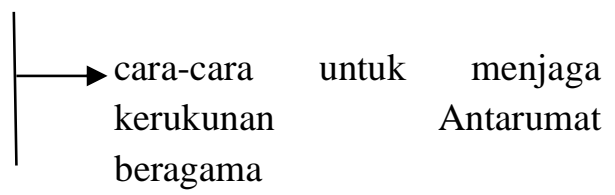

- Membagikan hewan kurban

- Sequence

- Bergaul dengan anggota keluarga

- Bergaul dengan teman sebaya

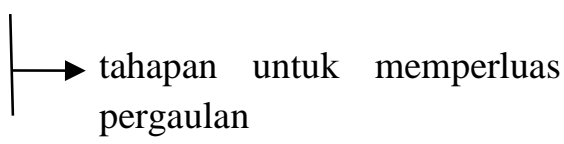

- Bergaul dengan masyarakat luas

- Attribution

- Tidak memaksakan keinginan

\begin{tabular}{l|l} 
- Membiarkan orang lain beragama sesuai keyakinan & $\rightarrow$ ciri orang yang toleran \\
- Mengakui dan menghargai perbedaan &
\end{tabular}

\section{Lembar Kerja Analisis Domain: ${ }^{31}$}

Format A

- Istilah tercakup

Hubungan semantik

Istilah pencakup

- Masjid

- Gereja

- Pura

Jenis

Rumah ibadah

- Tidak diskriminasi

- Adil

- Mengakui kesetaraan

${ }^{31}$ Ibid;257. 


\section{Analisis Taksonomi: ${ }^{32}$}

berbeda

menghormati pilihan orang lain yang

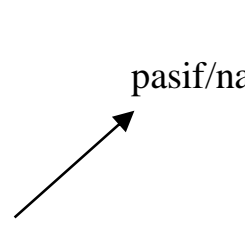

menerima perbedaan yang ada

reif menghindari sikap merasa benar sendiri

$\triangle$ tidak memaksakan pandangan dan keyakinannya

Jenis toleransi

$$
\text { kepada yang lain }
$$
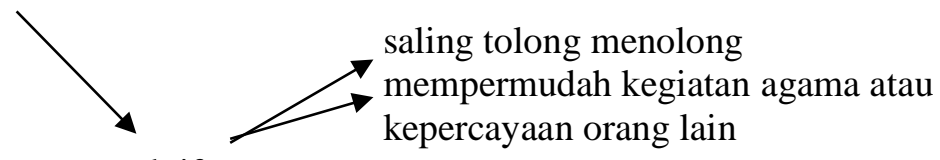

aktif

bagi

\section{Analisis Komponen: ${ }^{33}$}

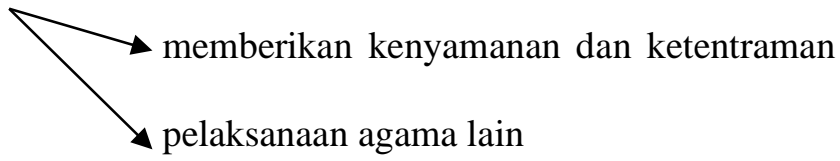

meringankan musibah umat lain

\begin{tabular}{|c|c|c|}
\hline 0 & \multicolumn{2}{|r|}{ Tipologi Keluarga Multi Agama di Balun } \\
\hline & \multicolumn{2}{|r|}{$\begin{array}{l}\text { Nenek beragama Hindu, ayah ibu beragama Islam, anak beragama } \\
\text { Islam, anggota keluarga lain beragama Kristen }\end{array}$} \\
\hline & .1 & $\begin{array}{l}\text { Nenek beragama Hindu, ayah ibu Islam, anak beragama } \\
\text { Islam, paman beragama Kristen }\end{array}$ \\
\hline & .2 & $\begin{array}{l}\text { Nenek beragama Hindu, ayah ibu Islam, anak beragama } \\
\text { Islam, bibi beragama Kristen }\end{array}$ \\
\hline & \multicolumn{2}{|r|}{$\begin{array}{l}\text { Ayah ibu beragama Islam, anak beragama Islam, anggota keluarga } \\
\text { lain beragama Kristen }\end{array}$} \\
\hline & .1 & $\begin{array}{l}\text { Ayah ibu beragama Islam, anak pertama beragama Islam, } \\
\text { paman beragama Kristen }\end{array}$ \\
\hline & .2 & $\begin{array}{l}\text { Ayah ibu beragama Islam, anak kedua beragama Islam, } \\
\text { paman beragama non Islam }\end{array}$ \\
\hline & \multicolumn{2}{|r|}{ Nenek Beragama Kristen, ayah ibu beragama Islam, anak beragama } \\
\hline & .1 & $\begin{array}{l}\text { Nenek beragama Kristen, ayah ibu beragama Islam, anak } \\
\text { pertama beragama Islam }\end{array}$ \\
\hline & .2 & $\begin{array}{l}\text { Nenek beragama Kristen, ayah ibu beragama Islam, anak } \\
\text { kedua beragama Islam }\end{array}$ \\
\hline & \multicolumn{2}{|r|}{$\begin{array}{l}\text { Kakek nenek beragama Kristen, orang tua (ayah ibu) beragama } \\
\text { Islam, anak beragama Islam, anggota keluarga lain beragama Kristen dan } \\
\text { Islam }\end{array}$} \\
\hline
\end{tabular}

\footnotetext{
${ }^{32}$ Ibid; 263-265.
}

${ }^{33}$ Ibid; 266-269. 


\begin{tabular}{|c|c|c|}
\hline & Kakek nenek beragama Kristen, orang tua (ayah ibu) \\
$\mathbf{. 1}$ & beragama Islam, anak beragama Islam, dua bibi beragama Kristen \\
\hline $\mathbf{2}$ & Kakek nenek beragama Kristen, orang tua (ayah ibu) \\
\hline & beragama Islam, anak beragama Islam, satu paman beragama Kristen \\
\hline $\mathbf{3}$ & $\begin{array}{c}\text { Kakek nenek beragama Kristen, orang tua (ayah ibu) } \\
\text { beragama Islam, anak beragama Islam, satu paman beragama Islam }\end{array}$ \\
\hline
\end{tabular}

\section{Pembahasan}

Berdasarkan hasil kajian di lapangan, eksternalisasi sikap toleransi anak melalui pendidikan informal dalam keluarga multiagama di Desa 'Pancasila' Balun Turi Lamongan mengambil bentuk realitas sosial sebagai berikut.

\section{a) Pengucapan 'Selamat Hari Raya Natal dan Nyepi'}

Terkait dengan realitas 'pengucapan selamat Natal dan Nyepi,' LS ${ }^{34}$, seorang anggota keluarga multiagama, berusaha menyesuaikan dirinya dengan kelompok yang pro atau menyetujui kebolehan mengucapkan 'Selamat Natal' kepada umat Kristiani yang sedang merayakan hari raya Natal, atau mengucapkan 'Selamat Nyepi' kepada umat Hindu yang sedang merayakannya. Masyarakat yang pro atau setuju dengan kebolehan mengucapkan 'Selamat Natal' atau 'Selamat Nyepi' sendiri merupakan bagian terbesar dari masyarakat Balun secara keseluruhan.

Ucapan "Selamat Natal" dari LS kepada ayah, ibu dan adik-adiknya merupakan bagian dari upayanya untuk melakukan penyesuaian dirinya atas sebuah entitas 'pengucapan Selamat Natal atau Selamat Nyepi' yang telah menjadi realitas sosial di desa Balun.

\footnotetext{
${ }^{34}$ Wawancara ini dilakukan di rumah pada tanggal 2 September 2017, jam 15.35 - selesai. Mbak Lis adalah nama panggilan akrab yang peneliti gunakan ketika mewawancarai informan ini. Nama lengkapnya adalah LS. Nama ini terkesan berbau Kristen, karena semenjak kecil LS adalah anak mengikuti agama Kristen dan hidup bersama kedua orang tuanya yang juga beragama Kristen, yaitu: Kar dan Mar. LS dilahirkan di Lamongan pada tanggal 5 Januari 1974. Sehingga kini, ia sekarang berusia lebih dari 44 tahun. Pendidikan terakhirnya adalah setingkat SMU atau sedejarat. LS terctatat sebagai anggota PKK desa Balun anggota Pokja III. Pekerjaan yang digeluti setiap hari adalah penjual dan pengoper ikan di pasar ikan Induk Lamongan. Ia kini tinggal dengan kedua orang tuanya di Balun, dan ia mempunyai seorang anak laki-laki; namanya LPS . Sebelum menikah, ia beragama Kristen. Namun, sesudah menikah, ia mengikuti agama suaminya, yaitu Islam.
} 
P: Terus koyok pean yo ngucapno selamat Natal nang keluarga opo nang tonggo-tonggo?

S: Yo iyo...biasa wae... sebab keluargaku lak akeh Kristene. Mosok aku meneng wae.. jelas bedo karo keluarga sing gak duwe keluarga ono sing mlebu Kristen. Mosok bapak, ibu lan adik-adik wes akeh sing bantu lan nguripe aku lan ananku...mosok aku mek meneng tok, Mas. Lak gak pantes dan kesane kok gak enak blass gara-gara wong jobo ono sing gak ngucapno selamat Natal. Kanggoku yo tetep aku ngucapno selamat Natal marang bapak, ibu lan adik-adik.... Sebalike yo ngono, Mas. Pan aku lebaran yo keluargaku, bapak ibu lan dulur-dulur ngucapno selamat lebaran kabeh. Ora mek ngono tok, malah adikku sing dadi tentara yo nukono sandangan kanggo aku dan anakku. Terus pean bayangno ...aku ora oleh ngucap selamat Natal sebab bedo agamo... lak gak kepenak dewe. Wong-wong sing gak urip sak omah karo keluarga bedo agomo sih enak wae..Mas

P: Pan wayahe Nyepi, yo pean ngucapno Selamat Nyepi nang tonggo pean?

S: Yo iyo..Mas. Mosok tonggo pepet omah ngene gak diparani dan diucapno Selamat Nyepi...engko lak dadi gak enake

P: Yo opo carane pean nyampekno ucapan selamat mou, Mbak..?

S: Yo tak parani siji..siji..wong omahe yo ora adoh...(WW.EMSHR1.LS.29-2017).

Kutipan data di atas juga menunjukan bahwa sikap toleransi LS dengan mengucapkan 'Selamat Natal' tidak hanya ditujukan kepada keluarganya, tetapi juga kepada tetangganya yang beragama Kristen. Di samping itu, ia juga mengucapkan 'Selamat Nyepi' kepada tetangga yang hidup di sebelah selatan rumahnya. Dalam mengucapkan 'Selamat Natal atau Selamat Nyepi,' ia tidak melakukannya melalui kiriman pesan singkat, baik WA, SMS, atau lainnya, tetapi ia menjumpai langsung orang-orangnya atau mendatangi tetangganya secara langsung satu rumah persatu rumah. 
Bahkan, ketika mengunjungi atau mendatangi tetangga-tetangganya, LS mengajak anaknya, LPS. Ajakan ini disengaja sebagai bentuk pendidikan toleransi langsung pada anaknya, bahwa hidup bertetanggaan itu harus saling menghargai dan menghormati, sehingga perbedaan yang ada, termasuk agama, tidak boleh mengendorkan semangat kerukunan dan keharmonisan dengan siapapun selama mereka masih tetap baik. Kutipan data berikut mengambarkan bagaimana EL mengunjungi tetangganya dan mengajak anaknya juga.

P: Terus karo tonggo yo ngono, Mbak?

S: Lho pan tonggoku iku ngerti lan apik karo aku lan keluarga lapo aku kok gak ngucapno Selamat Natal ..opo Selamat Nyepi...

P: Ngonoku pean yo ngajak anak opo dewenan pas nang tonggo-tonggo, Mbak

S: Yo...karo... Mas

P: Nah lapo kok ngajak anak barang.?

S: Yo supoyo anak tek ngerti...tek gak mung nang keluargane wae ngucapno selamat Natal lan Nyepi. Pas awak dewe riyoyonan... yo tonggo-tonggo sing Kristen lan Hindu pas dolan nang omah yo ngucapno selamat Idul Fitri....

P; Berarti pean parani tonggo-tonggo karo anake pean ?

S: Yo tak parani siji-siji sing omahe parek.. nek omahe keluarga sing rodok adoh kadang yo tak parani karo anakku kadang tak parani dewe.. (WW.EMSHR2.LS.2-9-2017)

LS dan anaknya tidak hanya mengucapkan 'Selamat Natal' atau 'Selamat Nyepi' sekali atau baru dua kali dalam hidup mereka, melainkan setiap hari Natal dan Nyepi tiba. LS selalu mengucapkan 'Selamat Natal' dan 'Selamat Nyepi' kepada tetangga-tetangganya secara rutin atau tiap tahunan. Seperti yang tersurat dalam kutipan data berikut.

P: Ngoneki yo pean lakoni ben tahun opo nek mek pas atine pean lagi enak opo seneng?

S: Yo ora toh, Mas. Yo ben taun... (WW.EMSHR3.LS.2-9-2017) 
Penyesuian diri terhadap realitas sosial yang berupa entitas ucapan 'Selamat Natal atau Selamat Nyepi' tidak hanya dilakukan oleh LS saja, melainkan juga oleh Rik. ${ }^{35}$ Bagi Rik, mengucapkan 'Selamat Hari Raya..' bukanlah fenomena kekinian atau realitas sosial yang baru saja muncul saat sekarang, melainkan sudah lama ada pada masyarakat Balun. Karena realitas ucapan 'Selamat Hari Raya..' ini sendiri merupakan realitas yang sudah lama dilakukan oleh orang-orang Kristen pada masa kepemimpinan kepala desa di pegang oleh Pak B selama 38 tahun. Begitu juga, umat Islam pada saat itu banyak yang membalasnya dengan mengucapkan 'Selamat Natal'.

Sebagai curahan dirinya atas realitas sosial yang ada di tengah masyarakat Balun, Rik tetap megucapkan 'Selamat Natal' kepada orang-orang Kristen, terutama ibu mertuanya, Munt. ${ }^{36}$.

Berikut ini merupakan kutipan wawancara yang menegaskan penyesuaian diri Rik terkait dengan realitas sosial ucapan 'Selamat Natal'.

P: Toleransi sendiri menurut Bapak itu kayak gimana?

\footnotetext{
${ }^{35}$ Wawancara ini dilakukan di rumah Pak Rik pada tanggal 7 September 2017, jam 18.15 selesai. Adapun kutipan-kutipan wawancara disajikan sesuai dengan topic yang ditanyakan. Namun demikian, pemberian latar belakang atau konteks secara sekilas juga penting untuk memahami subyek penelitian atau informan ini. Keluarga Rik terdiri atas 4 orang, yaitu: Rik, SC, RDP, dan Munt. Rik menduduki seksi ekonomi dan pemerintahan dalam struktur organisasi LPM desa Balun. Ia juga merupakan ketua RW III. Rik merupakan sosok kepala yang bertanggung jawab kepada keluarga. Ia sekarang merupakan salah satu Aparat Sipil Negara (ASN) di sekolah SMPN III Lamongan. Ia bertugas di bagian adiministrasi. Pria ini dilahirkan di Lamongan, tepatnya desa Balun. Jadi, ia merupakan putra Balun asli. Ia dilahirkan 47 tahun yang lalu; tepatnya ia dilahirkan pada tanggal 18 April 1971. Pria yang masih sangat terlihat gagah dan dempal ini merupakan anak pasangan Slm dan Krt. Saat ini ia sebenarnya sudah menyelesaikan program sarjana atau lulus S1, namun data kependudukannya tidak diperbarui atau tidak diupdate sehingga jenjang pendidikan yang masih tertera dalam KKnya adalah SMA atau sederajat. Ia menikah dengan seorang perempuan yang usianya tidak terpaut jauh, hanya 1 tahun saja. Perempuan yang beruntung bernama SC. Bersama SC, Rik dikaruniai seorang anak perempuan yang menginjak usia remaja menuju dewasa. Anak itu bernama RDP. Baik Rik, SC, dan RDP beragam Islam, sedangkan ibu menantu Rik, Munt, beragama Kristen. Mereka semua hidup dan tinggal seatap atau satu rumah. Karena pekerjaannya di lingkungan dinas pendidikan yang berada di jantung kota Lamongan, Rik setiap hari menggunakan bahasa Indonesia, sehingga ia sudah sangat fasih atau lancar dalam berbicara Indonesia. Oleh karena itu, peneliti menggunakan bahasa Indonesia dalam mewawancarai Rik (subyek atau informan penelitian).

${ }^{36}$ Munt adalah seorang yang beragama Kristen. Ia adalah ibu mertua dari Rik.
} 
S: Kalau saya sih ...toleransi bukan hanya sekedar membiarkan orang lain menjalankan ibadah agamanya, atau mengakui perbedaan agama.... malah kalau saya toleransi itu harus bisa saling memahami, saling bekerja sama, saling membantu, gitu...Pak

P: Oh gitu...tapi seikap toleransi kayak ini pernah gak dilakukan oleh orangorang sebelumnya, Pak

S: Dulu pas ketika kepala desanya Pak B... Gak ada orang yang ramai atau meributkan ucapan Selamat Natal atau Nyepi. Mantan petinggi Sud yo sering ngucapno Selamat Idul Fitri atau Lebaran kepada umat Islam sini, dan tidak ada yang protes. Jadi, jika Bapak mendengar larangan mengucapkan Selamat Natal kepada umat lain, saya gak tahu ceritanya gimana, dan siapa yang mencontohkannya? (WW.EMSHR1.R.7-9-2017)

Sama dengan LS dalam menyampaikan ucapan 'Selamat Natal maupun Selamat Nyepi', Rik juga mendatangi para tetangga yang berbeda agama tersebut seperti tampak pada kutipan data berikut ini.

P: Bagaimana Bapak menyampaikan ucapan 'Selamat Natal atau Nyepi' kepada tetangga pean sekaligus warga pean, Pak?

S: Bahkan, saya tidak hanya mengucapkan lewat WA atau SMS, melainkan mendatangi mereka dari rumah ke rumah....(WW.EMSHR2.R.7-92017)'

Ucapan 'Selamat Natal' tidak hanya dilakukan oleh Rik sendiri kepada ibu mertuanya, tetapi juga dilakukan oleh anaknya. Rist. Bahkan, Rist tidak hanya sekedar mengucapkan 'Selamat Natal' tetapi ia juga memberikan hadiah kepada neneknya, ibu Munt.

P: Apa anak juga mengucapkan 'Selamat Natal' kepada neneknya?

S: Ya iya... Pak. Malah dia yang tiap hari tidur sama neneknya.

P: Apa anak Bapak..Siapa namanya.Pak?

S: Rist..

P: Ya Rist apa hanya mengucapkan 'Selamat Natal' saja kepada neneknya..? 
S: Biasanya sambal memberikan hadiah....kadang kebaya, kadang kain, kadang sandal...gak mesti kok..Pak (WW.EMSHR3.R.7-9-2017)

Begitu juga, Rik mengajak anak dan istrinya untuk mengucapkan 'Selamat Natal atau Selamat Nyepi' kepada para tetangga dan atau warganya yang beragama Kristen dan Hindu. Dengan mengajak anaknya, Rik secara sadar atau tidak telah mendidik anaknya untuk bersikap toleransi kepada tetangga dan warganya tersebut, dan mungkin untuk menjaga hubungan sosial atau kohesi sosial yang lebih baik.

P: Apa Bapak pernah mengajari Rist untuk mengucapkan Selamat Natal..?

S: Ketika kecil ya..iya...tapi sekarang kan sudah besar kan bisa melakukannya sendiri. Ia juga sudah bisa membedakan mana sikap toleransi yang diperbolehkan dan mana yang tidak boleh..?

P: Berarti Pak Rik memberikan contoh atau keteladanan ya kepada Rist...?

S: Ya iya.... (WW.EMSHR4.R.7-9-2017)

Realitas kehidupan yang berupa pengucapan 'Selamat Natal' tidak hanya terjadi pada LS dan keluarga Rik, tetapi juga pada keluarga Pur. ${ }^{37}$ Pur juga melakukan penyesuian diri terhadap realitas tersebut. Penyesuaian ini tidak hanya dilakukan ketika ia ingat atau lagi ada keperluan apa di balik pengucapan 'Selamat Natal atau Selamat Nyepi' seperti yang dilakukannya kepada adiknya, BY. Berikut ungkapana kutipan yang setidaknya menunjukan entitas pengucapan Natal pada keluarga Pur.

P: Ngapuntene..Mas. Opo pean yo ngucapno Selamat Natal nang tonggotonggo sing ngerayano Natalan?

\footnotetext{
${ }^{37}$ Wawancara dilakukan di rumah pada tanggal 15 September 2017. Informan ini dilahirkan di Lamongan pada tanggal 9 - 4 1974. Ia memiliki seorang istri yang bernama EM, dan dua anak, yaitu: KA dan ENS. KA dilahirkan di Lamongan pada tanggal 23 - 12 - 1999, sedang ENS juga dilahirkan di Lamongan pada tanggal $3-2$-2004. KA sekarang bekerja sebagai penjaga toko di sebuah swalayan di kota Lamongan, sementara ENS masih duduk di SMPN 3 Lamongan. Baik EM, KA dan ENS, mereka semua beragama Islam. Pur sebelum menikahi EM beragama Islam. Pur saat ini masih memiliki seorang saudara laki-laki, yaitu BY. BY kini tinggal serumah dengan Pur, namun BY kini berlainan agama dengan Pur, karena BY memeluk agama Kristen. Sementara itu, kedua orang tua Pur, yaitu: Am dan Km, telah meninggal dunia. Pur menyelesaikan pendidikannya di tingkatan Sekolah Menengah Atas (SMA), dan sekarang ia berprofesi sebagai pekebun dan petambak.
} 
S: Ning ngucapno yo iyo... ben taun aku slalu ngucapno 'Selamat Natal' nag wong-wong...

P: Pean ngucapno iku, opo ono karepe..?

S: Yo gak ono karepe, Mas. Mek tetanggane iku ben rukun...

P: Mss yo ngucapno 'Selamat Natal' nang adik pean?

S: Yo ngucapno lho, Mas. Mosok demani adik dewe terus meneng ae... yo ora.

P: Yo kan .....Mas B kan melu pean...?

S: Masio ngono... yo gak terus gak diwei ucapan 'Selamat Natal'. Sak umpomo awak dewe iki ora sing ngucapno, terus sopo...? (WW.EMSHR1.P.15-9-2017).

Dari kutipan wawancara di atas, Pur tidak hanya mengucapkan 'Selamat Natal' hanya kepada tetangganya, melainkan juga kepada adiknya, BY. Ucapan 'Selamat Natal' ini bertujuan mempererat tali persaudaraan sekandung dan rasa iba, serta memkuat kohesi sosial di tengah masyarakat Balun. Di samping itu, Pur tidak mengucapkan 'Selamat Natal' satu atau dua kali, melainkan setiap hari Natal datang, ia selalu melakukannya. Dengan demikian, penyesuaian diri Purnomo terhadap reliatas sosial berupa ucapan 'Selamat Natal' telah menjadi agenda tahunan yang harus dilakukan oleh Pur.

Berbeda dengan ayahnya, Pur, yang hanya mengucapkan 'Selamat Natal' kepada BY, CA, anak Pur, mengucapkan 'Selamat Natal' tidak hanya dengan lisan saja atau bahasa verbalis, tetapi mereka juga memberikan hadiah, baik berupa celana, kemeja, kaos atau lainnya sebagai symbol ucapan 'Selamat Natal'. Berbeda dengan CA, ENS mengucapkan 'Selamat Natal' dengan disertai pelukan dan ciuman kasih sayang. ENS melakukan hal ini setiap hari Natal tiba. Fakta ini tampak tergambar dalam kutipan wawancara berikut.

S: Yo iyo..Mas. Ben riyoyo Natal... malah biasane anakku sing mbarep nukono hadiah nang adikku, Budi.

P: Oh ngono... terus pan karo adikne piye, Mas...?

S: Yo biasanya ngesun opo ngambung tok.. (WW.EMSHR2.P.15-9-2017)' 
Dari kutipan data di atas, Pur telah menanamkan sikap toleransi pada kedua anaknya sejak kecil melalui pendidikan yang ada dalam keluarga. Pendidikan toleransi ini penting dilakukan untuk membekali anak-anaknya menjadi pribadi yang toleran dan tidak kaget jika kelak hidup dengan orang yang tidak seagama dengan mereka.

Lebih jauh lagi, Pur pun mengajak anak-anak dan istri jika mereka sedang ada di rumah pada saat hari raya Nyepi. Ia mengajak mereka untuk berkeliling mengucapkan 'Selamat Nyepi', meskipun ia sendiri tidak memiliki keluarga atau kerabat yang beragama Hindu.

Berikut merupakan kutipan wawancara yang secara tersurat menyatakan fakta kunjungan Pur dan keluarganya kepada tetangga mereka yang beragama Hindu. .

P: Karo ngejak anak bojo, opo dewean?

S: Kadang yo karo bojo tok, kadang yo karo anak.. pan anaken nang omah

P: Gak duwe keluarga Hindu to.. Mas?

S: Keluarga Hindu sih aku gak duwe, tapi nek konco Hindu yo akeh... (WW.EMSHR3.P.15-9-2017)'

Berdasarkan hasil survey partisipasi, peneliti tidak melihat sebagian umat Islam tidak hanya ikut menjaga gereja, tetapi juga mengucapkan 'Selamat Natal'. Begitu juga, ketika upacara atau pawai Ogoh-ogoh selesai, banyak pemuda Islam yang mengucakan 'Selamat Nyepi' kepada umat Hindu. Peneliti mendengar sendiri beberapa pemuda Islam mengucapkan kata tersebut di lapangan desa Balun ketika proses pembakaran patung Ogoh-ogoh akan selesai. Begitu juga, Pak Khusayri, kepala desa Balun, menyampaikan ucapan ‘Selamat Nyepi’ pada umat Hindu. Dengan demikian, ucapan 'Selamat Natal atau Nyepi' bukanlah realitas kehidupan yang terjadi pada keluarga multi agama, tetapi hidup pada orang-orang menyukai sikap toleransi dengan berbagai cara.

\section{b) Menerima Perbedaan dan Saling Menghormati}

Setiap orang yang tinggal di Balun pasti mengetahui bahwa Balun bukanlah desa yang monoreligi atau monoagama, melainkan multi agama. Setidaknya ada tiga agama yang hidup dan berkembang di Balun. Ketiga agama tersebut adalah Islam, 
Kristen dan Hindu. Keberadaan agama yang berbeda-beda ini mensyaratkan atau meniscyakan adanya sikap legowo atau sikap nerimo pada diri masyarakat Balun. sehingga, setiap indvidu yang ada di Balun dituntut untuk menerima perbedaan agama yang ada.

Perbedaan agama yang ada di Balun terbukti tidak membuat masyarakat hidup di dalamnya menjadi tersekat atau terpisah-pisah menurut agama yang mereka anut atau peluk, sebaliknya mereka bisa hidup damai dan rukun serta harmonis dalam satu RT, satu RW atau satu dusun. Bahkan, di antara mereka ada yang hidup saling berdekatan atau bertetanggaan langsung.

LS merupakan subyek penelitian yang hidup berdampingan atau bertetanggaan langsung dengan umat Hindu. Rumahnya yang berdampingan langsung dengan tetangga Hindu ini, apa pun yang mengeluarkan suara bisa terdengar samar, bahkan jelas dari rumah tetangganya. Dengan kata lain, suara apapun yang berasal dari rumah keluarga LS akan terdengar jelas dari rumah tetangga Hindunya tersebut. Misalnya, ketika keluarga LS menghidupkan atau membunyikan tape atau TV dengan suara lumayan keras, makanya tetangganya yang Hindu yang berada di sisi kiri rumahnya persis akan bisa mendengarnya dengan jelas.

Begitu juga, ketika keluarga LS menyalakan lampu listrik atau menstarter sepeda motor, maka tetangganya yang Hindu pun bisa melihat dengan jelas atas penggunaan listrik dan mendengar suara sepeda motor yang dinyalakan. Oleh karena itu, setiap hari raya Nyepi tiba, keluarga LS berusaha mematikan lampu listrik, tidak menstarter sepeda motor di dalam rumah atau depan rumah, menyalakan tape dan TV dengan keras atau kencang, melainkan dengan suara sangat pelan dan lirih. Hal ini terpaksa LS lakukan karena anaknya, LPS, terkadang merengek dan menangis ketika minta TV disetel untuk melihat film atau acara kesukaannya. Berikut kutipan wawancara LS yang menunjukkan sikap toleransi kepada tetangganya yang merayakan Nyepi.

P: Mbak..Kidul omah iki lak agamane Hindu... Terus koyok dino Nyepi ngonoku piye, Mbak..?

S: Maksute..? 
P: Maksute opo keluarga iki yo tetap nyetel TV banter, opo TV ne dialusno

S: Yo tetep distel, tapi gak banter-banter nemen. Engko krungu karo tonggo yo gak enak, Mas.

P: Berarti lampu listrik tetap nyala biasa yo koyok bendino yo.....?

S: Nggak...Masio awak dewe ora duwe keluarga Hindu.. dadi yo tetap matine listrik lan lampu..

P: Putro yo sek biasa game-gameman...?

S: Yo... iyo... piye maneh jenenge bocak cilik...tapi yo takon nyilikno suarane supoyo gak krungu teko joboh. Gak enak nek sampek krungu teko kidule omah

P: Terus bocahe gelem, Mbak..?

S: Gelem....

P: Misale pan poso opo wayahe Magrhib pas pan pean sholat ngono, tonggo kidul iki yo matino opo ngecilno tape opo TV?

S: Ning matine koyoke jarang, tapi ning nyilikno memang tak akui..

P: Oh ngono..berarti sampeyan matine lampu lan liyoliyo iku gawe bales toleransi tonggo..

S: Wong jenenge urip tetonggo, yo kudune podo ngertine...Mas (WW.EMPSM1.LS.2-9-2017)

Mematikan listrik, tidak membunyikan atau menstarter sepeda motor di depan atau di rumah yang suaranya bisa terdengar bagi orang yang merayakan Nyepi, atau tidak membunyi tape dan menyalakan TV merupakan sikap toleransi yang dilakukan oleh umat Islam dan Kristen di desa Balun.

Berdasarkan pengamatan atau survey langsung peneliti ke Balun saat Nyepi, desa Balun kelihatan sangat sepi dan lengang. Tidak ada aktivitas yang dilakukan di luar rumah oleh masyarakat, baik yang beragama Islam maupun Kristen, kecuali anakanak yang bermain sepak bola di halam masjid atau lapangan desa. Begitu juga, rumah-rumah yang bertetanggan dengan umat Hindu lampunya banyak tidak menyala atau dimatikan sementara. Tidak ada suara tape dengan sound system terdengar menggelegar atau keras seperti hari-hari biasanya. Pada saat Nyepi, Balun benar-benr 
menjadi 'desa yang mati.' Dengan demikian, sikap toleransi dalam bentuk menerima perbedaan dan saling menghormati, terutama ketika hari Nyepi dengan tidak menyalakan listrik, lampu, sepeda motor, tape, TV dan lainnya tidak hanya menjadi realitas hidup pada keluarga LS semata, tetapi sudah menjadi realitas bersama pada masyarakat Balun. Dalam konteks yang sedemikian ini, proses eksternalisasi yang terkait dengan sikap toleransi menerima perbedaan dan menghormati perbedaan telah terjadi.

\section{c) Tidak Mendeskritkan Ibadah Umat Lain}

Selama tinggal di Balun peneliti tidak pernah mendengar antar umat beragama saling menghina, saling mencemooh, saling merendahkan, atau lainnya tentang ritual keagamaan atau model ibadah agama mereka, padahal sikap atau tindakan saling menghina, saling meremehkan, atau saling menjelekan setiap hari bisa terjadi. Karena, bukan hanya umat Islam yang setiap hari datang ke masjid, tetapi juga umat Hindu dan Kristen bisa saja datang kapan pun ke pura atau ke gereja. Apalagi, letak ibadah atau ritual keagamaan mereka saling berdekatan antara satu dengan lainnya.

Tidak hanya itu, umat ketiga agama di Balun ini sering berjumpa atau berpapasan ketika mereka ada yang mau berangkat beribadah atau pulang ibadah dari masjid, gereja maupun pura. Artinya, lima kali mereka bisa bertemu atau berjumpa jika mereka mau atau ingin, namun tidak ada satu pun individu atau penganut agama di Balun yang mendeskritkan atau mengolok ibadah umat lain. Tidak mendeskritkan atau mengolok agama atau umat lain telah menjadi realitas kehidupan di Balun; dan sebagai realitas kehidupan yang tumbuh dan berkembang di Balun, maka setiap individu hidup di Balun pasti berusaha menyesuaikan diri di dalamnya.

Demikian juga yang terjadi pada diri LS. Ia menyadari bahwa kerukunan, keharmonisan dan kedamaian dalam keluarganya yang multi agama itu hanya bisa terwujud ketika semua anggota keluarga yang ada bisa saling mengakui, menghargai dan menghormati perbedaan agama yang ada di antara mereka, bukan saling menjelekan, meremehkan atau mendeskritkan. Oleh karena itu, LS berusaha menyesuaikan diri dengan realitas kehidupan yang ada di Balun. 
Kutipan wawancara berikut ini menunjukan penyesuaian diri LS terhadap apa yang dilakukan oleh orang tuanya ketika mereka melakukan kebaktian, doa atau lainnya di rumah.

P: Berarti pan bapak karo ibu ora nang gerejo, terus kebaktian opo doa nang omah dewe, Mbak Lis gak keberatan?

S: Yo ora...

P: Bok menawi Mbak Lis tau keberatan..?

S: Gak...Mas. Nah lapo Mas aku keberatan wong iki yo omahe Bapak.

Sakjane yo Bapak karo Ibu sing keberatan sebab mbendino aku sembahyang nang omah...

(WW.ETMIUL1.LS.2-9-2017)

Lebih lanjut, LS juga mengingatkan anaknya, LPS, agar tidak mencemooh apa pun yang dilakukan baik oleh kakek neneknya maupun oleh bibi-bibi dan pamannya. Kutipan data di bawah ini memuat larangan-laranag bagi LPS untuk untuk mencaci, memaki, menghina, menjelekan, meremehkan, dan sejenis terhadap aktivitas keagamaan yang dilakukan oleh kake nenek, dan bibib-bibinya..

S: Yo iyo.... Lan tak kandani barang nek mbah karo bibi-bibi nang gereja opo ngelakoni sembahyang ojo diganggu opo dielokno..barno bahe... tapi pan iso bantu mbah opo bibi pan dikonkon jupuk opo to opo...

P: Terus sak liyone iku..piye carane Mbak ngajari anake Mbak toleran karo mbahne opo bibine?

S: Yo tak kei contoh nek bibi opo mbah nyanyi-nyanyi lagu gereja ojo dilokno opo dipaido. Nek mbah lan bibi ape nang gereja misale ojo diganggu opo direpoti. Pokok e wes koyok ngono lah..

P: Ono iku Mbak tekano nang Putra..?

S: Iyo..Mas. Mosok aku ngajari anakku ..'lapo mbah lapo bi...nang gereja barang..' ' '...opo kandani mbah lan bibi...ojo nyanyi banter-banter suarane gak enak tur wayahe wong turu..' yo ora to Mas.. (WW.ETMIUL2.LS.29-2017) 
Dari kutipan di atas juga kita memahami bahwa relasi keluarga yang dilakukan oleh LS tidak hanya dibangun dengan kedua orang tuanya, melainkan melibatkan adik-adiknya juga, yaitu: DKW, MDS, dan WS. Untuk menjaga keluarga yang baik, ia tidak pernah merintangi adik-adiknya untuk pergi ke gereja, baik untuk acara kebaktian, misa, nyanyi dan lain sebagainya, apalagi merendahkan, menghina, meremehkan dan lain sebagainya.

Tidak berbeda jauh LS, Rik, istri dan anak-anaknya juga harus melakukan penyesuaian diri dengan realitas sosial yang hidup di desa Balun. dalam konteks ini, realitas yang dimaksudkan adalah tidak mendeskritkan ibadah umat lain. Penyesuaian diri Rik misalnya dilakukan dengan mensejajarkan foto kaligrafi ayat kursi dengan foto Yesus Kristus, padahal ia memiliki kesempatan untuk melakukan pelecehan atau penghinaan secara tidak kentara kepada ibu mertuanya, yakni dengan memasang kaligrafi ayat kursi di atas foto Yesus Kristus. Namun, hal itu tidak ia lakukan.

Berikut kutipan wawancara yang menggambarkan hal tersebut.

P: Pak... Bapak ini beruntung sekali ya punya ibu mertua yang sangat pengertian..

S: Beruntung gimana?

P: Ya... beruntung... Bapak kan tidak perlu membangun rumah. Rumah sudah disediain mertua. Istri ikut agama Bapak. Terus itu....(sambal menunjuk ke kaligrafi yang terpasang di dinding rumah)... Bapak tidak dilarang menempel figura kaligrafi di rumah ini.

I: Oh gitu toh..Pak maksudnya.

P: Terus ibu mertua Bapak juga kelihatan banget orang yang mengalah?

S: Kok Bapak...kok tahu...

P: Ya itu..tu... Foto Yesus masak diletakin sejajar dengan kaligrafi. Jika ibu mertua Bapak orang yang gak mau mengalah, kan pasti tidak mau. Atau setidaknya dipasang di atasnya....

S: Jeli juga ya Sampeyan itu.... Tapi Bapak harus itu, itu foto Yesus bukan mertua yang beli, tapi saya yang beli. Saya lihat di rumah-rumah orang Kristen di sini kan ada banyak pohon Natal dan foto Yesus, cuman di 
rumah ini saja yang gak ada... tapi saya membaca mungkin ibu mertua butuh ffigura berisi foto Yesus, dan ternyata benar. Ia sangat senang dengan adanya foto Yesus di rumah meski diletakan di atas kaligrafi atau sejejer. Saya belikan itu sebagai rasa hormat saya dan saya sangat menghargai ibu mertua saya yang tiada henti melayani dan mengerti kehidupan kami, terutama istri dan anak saya. (WW.ETMIUL1.R.7-92017)

Sikap toleransi dengan tidak menghina atau menjelekan ritual agama lain tidak hanya dilakukan oleh keluarga LS dan Rik saja, melainkan juga dilakukan oleh keluarga Pur. Ia tidak hanya meminta anaknya untuk menghina adiknya, BY, misalnya dengan menyebut 'mengapa paman harus menyembah patung..?' jika ia mengajari anaknya seperti itu, maka hal itu bisa menimbulkan persoalan atau permasalahan di tengah masyarakat Balun.

Begitu juga, Pur tidak pernah mengajari anaknya untuk menggugat atau mengkritis orang Hindu dengan bertanya 'untuk apa sih orang Hindu membuat patung Ogoh-ogoh dengan ukuran raksasa dan mengeluarkan biaya yang tidak sedikit, kemudian akhirnya dibakar. Kok seperti tidak ada kerjaan lagi? Sebaliknya, Pur meminta anaknya untuk tidak mencampuri apa yang umat Hindu lakukan, atau meminta anaknya mempertanyakan maksud atau tujuan pembuatan patung Ogohogoh dengan biaya besar, tapi akhirnya dibakar sendiri.

Di samping itu, Pur juga tidak ingin menyebarkan keresahan atau kericuhan di tengah masyarakat dengan mengjelek-jelekan ritual agama lain, karena ketika ia juga di'serang' balik dengan dipertanyakan, apalagi sampai diejek tentang ritual keagamaan seperti sholat, yakni sembahyang kok jungkar balik, mencium tanah dan lain sebagainya, mungkin kita tidak terima. Oleh karena itu, Pur lebih membiarkan umat Hindu untuk menjalankan ritual ibadah mereka tanpa mendapatkan hinan, cemoohan, atau sejenisnya. Hal ini tampak tersurat dalam kutipan wawncara berikut ini.

P: Yo tau ngulangi anake pean kon gudo... 'Lapo Pak Lik Bud nyembah patung' misalnya? 
S: Wa garai gak enak ngono iku... engko tambah krungu wong akeh dadi ramene..lan dadi tukarane..

P: Oh ngono... tapi karo wong Hindu piye..?

S: Wes ..Mas. aku gak tau ngulangi anak-anaku ngeyek wong liyo..engko tambah dadi gak enake dewe..

P: Pean yo opo tau ngomongno 'nah yo lapo wong Hindu iku, patung Ogohogoh digawe-gawe dewe, mari ngono diobong-obong dewe..lak kurang gawe to ngonoku' misale koyok ngono...?

S: Gak tau koyok ngono, Mas. Yo barno ae lah Mas. Gak ngurusi urusane agamane wong liyo.. mundak engko dibalikno yo awak dewe gak trimo...

P: Misale piye...?

S: Nang dibalikno...misale 'awakmu lho lapo..sembahyang.. kok jungkar jungkir..kok gak sing enak lunggoh kursi to piye' ngono laky o gak enak to, Mas.

P: Berarti wong kene yo gak tau ngelekno antarane siji lan liyone yo, Mas..

S: Sak weruku ngono.. (WW.ETMIUL1.P.15-9-2017)

Tidak mau menghina atau menjelekan ibadah umat lain tidak hanya dilakukan ketika adiknya melakukan kebaktian atau mencemooh pawai Ogoh-ogoh sebagai rangkaian dari perayaan Nyepi dalam hitungan minggu, bulan atau setahun saja, melainkan setiap waktu ketika kebaktian diadakan di gereja dan pawai Ogoh-ogoh dan Nyepi setiap tahun.

Dengan demikian, sikap toleransi dengan tidak menghina, mengejek, menjelek, merendahkan dan sebagainya yang selalu dilakukan oleh ketiga subyek penelitian ini (LS, Rik dan Pur) di tengah kehidupan masyarakat Balun yang multi agama memiliki basis pijakan normative maupun sosiologis.

\section{Simpulan}

Berdasarkan paparan pembahasan di atas, eksternalisasi sikap toleransi anak melalui pendidikan informal dalam keluarga multiagama di desa Pancasila Balun Turi Lamongan dilakukan dengan cara sebagai berikut: 
a) menyesuaikan diri terhadap fenomena dan atau realitas sosial seperti pengucapan 'selamat hari raya', menerima perbedaan dan saling menghormati, dan tidak mendeskritkan ibadah umat lain;

(b) memakai pesan pendek yang berupa whatsapp atau instagram dan sejenisnya untuk menyesuaikan diri terhadap sikap toleransi yang ada dan tumbuh di masyarakat Balun;

(c) mengajak anak-anak bertamu untuk mengucapkan 'selamat hari raya..' ke tetangga yang berbeda agama, atau bertandang ke rumah-rumah orang-orang berbeda agama satu persatu sebagai upaya identifikasi diri di tengah sikap toleransi yang tumbuh di masyarakat Balun;

(d) mencontohkan anak-anak bersikap toleransi dengan merujuk pada peristiwaperistiwa sebelumnya; dan

(e) menemukan sandaran atau pembenaran atas pembentukan sikap toleransi anak di Balun.

\section{DAFTAR PUSTAKA}

Mackey, Alison. Second Language Research: Methodology and Design. New Jersey: Lawrence Erlbaum Associates, Inc. 2005.

Thomas R. Lindlof. Qualitative Communication Research Methods. USA: SAGE Publications, Inc. 1995.

Mudrajat Kuncoro. Metode Riset. Jakarta: Erlangga. 2003.

Bruce L Berg. Qualitative Research Methods for the Social Science. USA: Allyn dan Bacon, 1989.

Matthew Miles B \& A. Michael Huberman. Analisis Data Kualitatif. Terj. Tjejep Rohendi. Jakarta: UI, tt.

Donald Ary et.all. Introduction to Research in Education. USA: Holt Rinehart and Winston, $\mathrm{tt}$.

James Dean Brown. Understanding Research in Second Language Learning. NY: Cambridge Univ. Press, tt.

M. Djunaidi Ghony dan Fauzan Almanshur. Metodologi Penelitian Kualitatif. Yogyakarta: ar-Ruz Media. 2012.

J. W. Creswell. Qualitative Inquiry and Research Design Choosing Among Five Traditions, Thousand Oaks: Sage, 1998. 
. Mixed Method Research: Introduction and Application, dalam G. J. Cizek, Ed. Handbook of Educational Policy. San Diego: Academic Press, 1998.

Sanapiah Faisal. Format-format Penelitian Sosial: Dasar-dasar dan Aplikasi. Jakarta: Raja Grafindo Persada, 1995.

Masykuri Bakri, Dkk. Metode Penelitian Kualitatif: Tinjauan Teoritis dan Praktis. Malang: LP UNISMA Malang, 2013.

Jan Jocker dan Bartjan Pennink. The Essence of Research Methodology: A Concise Guide for Master and PhD Students in Management Science. Berlin: Springer, 2010, 80-81.

James Spreadly. Participant Observation. USA: Holt Rinehart and Winston, 1980.

David Silvermen. Interpreting Qualitative Data: Methods for Analyzing Talk, Text, and Interaction. Great Britain:

the Crowell Press, ltd, 1995, 8-19.

John W. Creswell. Penelitian Kualitatif \& Desain Riset. Yogyakarta: Pustaka Pelajar, 2014.

Ibrahim Bafadal dan Masykuri Bakri. Metode Penelitian Kualitatif: Tinjauan Teoritis dan Praktis. Malang: LP UNISMA dan Visipress Media, 2013.

Sugiyono. Metode Penelitian Kuantitatif, Kualitatif dan R \& D. Bandung: Alfabeta, 2014. 